\title{
Sand-Dunes in the Peruvian Desert
}

\section{Author(s): W. S. Barclay}

Source: The Geographical Journal, Vol. 49, No. 1 (Jan., 1917), pp. 53-56

Published by: geographicalj

Stable URL: http://www.jstor.org/stable/1779781

Accessed: 31-05-2016 08:11 UTC

\section{Your use of the JSTOR archive indicates your acceptance of the Terms \& Conditions of Use, available at}

http://about.jstor.org/terms

JSTOR is a not-for-profit service that helps scholars, researchers, and students discover, use, and build upon a wide range of content in a trusted digital archive. We use information technology and tools to increase productivity and facilitate new forms of scholarship. For more information about JSTOR, please contact support@jstor.org.

The Royal Geographical Society (with the Institute of British Geographers), Wiley are collaborating with JSTOR to digitize, preserve and extend access to The Geographical Journal 
But now she has the distant countries found, High praise will lands, both great and small, propound.

And what should Earth of Hakluyt's story say?

All Earth,-no less, its mead to him will pay."

We see, then, that the introducers of Hakluyt's great work to the public were Richard Mulcaster, Pigafetta, Hugh Broughton, and William Camden. That is the complete list. It is mainly, perhaps entirely, a list of teachers. Mulcaster, the trainer of teachers and the advocate of the school teaching of drawing, here directly identifies himself with enthusiasm for the aims of Hakluyt, as a developer of the history of geographical discovery. Pigafetta probably was a teacher of Italian, at any rate, whilst in England. Broughton is a pioneer in the teaching in England of Hebrew and oriental languages. William Camden was at the head of English schoolmasters, with the possible exception of Mulcaster himself.

\section{SAND-DUNES IN THE PERUVIAN DESERT}

\section{W. S. Barclay}

TN February I9I I, being stationed for some time at La Paz, Bolivia, I 1 took the opportunity of visiting the Pampa del Sacramento in its stretch of about 50 miles between Arequipa and the Pacific coast-hills. This Pampa (the word is used here in the sense of "level ground") is really a continuation of the barren lands of Northern Chile, characterized by Charles Darwin ('Voyage of the Beagle') as one of the true desert spots in the world; it is crossed transversely by the southern railway of Peru. A remarkable feature of the Pampa del Sacramento is its moving sand-dunes, and it was to study the formation and action of these dunes that my visit was made.

Although the majority of the dunes are to be found in the western half of the Pampa the sub-aerial weathering of the conglomerate bed from which they take their origin is noticeable elsewhere along the Peruvian coast. One of my most vivid recollections on the steamer voyage along the desolate coast from Lima to Mollendo is a vision, against the early morning sun, of a great flame-coloured hill that seen through the coast fogs presented almost the appearance of a city on fire. This flame effect was, as I afterwards ascertained, due to sand and dust blowing across its upper ridges.

Starting from Mollendo the railway winds its way up the deeply eroded flanks of the coast hills. The hot air rising from the desert keeps back or dissolves the clouds which attempt to make their way across the Andean crests to the sea, and rain is reckoned to fall on this coast not more than once in seven years. When this occurs, however, its erosive effect on the soft, loose soil is striking. Watercourses ${ }_{5} 5$ to 20 feet deep are cut in a 
few hours. One of these rare rain phenomena had taken place a few days before my visit. It does not pay the railway, when constructing its track, to allow openings for these infrequent cloud-bursts, and one sees in consequence solid earth-banks built along the hill-flanks, damming gulleys of great depth extending sometimes a mile or more on the up-side.

On reaching the Pacific fringe of the Pampa, or Desert, del Sacramento, after an ascent from the coast of some 4000 feet, one begins to feel the wind which is responsible for the formation of the dunes. The general direction of this wind is from the north-west, being caused by radiation from the desert surface and the consequent inrush of cooler air from the Pacific. It blows at about 20 miles an hour, and the sand which it releases travels about 2 miles an hour on the hard flat surface between the ridges. The wind starts as soon as the desert warms up and increases in violence with the rising temperature, attaining its maximum force between 2 p.m. and sunset.

The conglomerate bed of this desert Pampa is chiefly formed of the following constituents, in order of their importance: quartzite, tufa, gypsum, diorite (with iron and pyroxin crystals), and quartz. The whole is packed and blended by the gypsum which has run into and filled fractures made perpendicularly, thus facilitating weathering. The tufa is found in beds'also in the neighbourhood of Arequipa, and is cut into blocks for building purposes. They ring when struck like well-burnt bricks. The quartzite forms the main mass of the hills surrounding the desert. It weathers into a brick-red oxide on the surface, which gives the desert its tone, making the slaty-white sand-dunes noticeable by contrast. The quartz is infrequent. Diorite is interspersed in the conglomerate, but in angular form showing no signs of water-wearing; it must therefore be attributed to volcanic ejecta. The genesis of the sand-dunes is best seen on the Pacific or western fringe of the desert, where the winds are eating away the conglomerate ridges (possibly the remains of an ancient higher level), which run out from the quartzite hills in a direction at right angles to the prevailing winds.

On the western border of the desert the sand remains largely inchoate, but after about 15 or 20 miles dunes begin to appear, and these increase in number till on nearing the inland fringe, some 25 miles from Arequipa, they can be observed in serried battalions accompanying the railway.

Once formed, the dunes take their typical half-moon shape and proceed in stately sequence south-east across the Pampa until they reach some large obstacle or abrupt change of level. If the barrier is negotiable they adapt themselves to cross it, the dune projecting itself into the easiest passes and elongating up to the limit of its sand-mass. Once the obstacle is crossed, the vanguard of the dune marks time until the rear catches up, forms once more into a half-moon shape and proceeds on its way. These dunes often attain a considerable size, measuring up to $5 \circ$ yards between the points of the horns. 


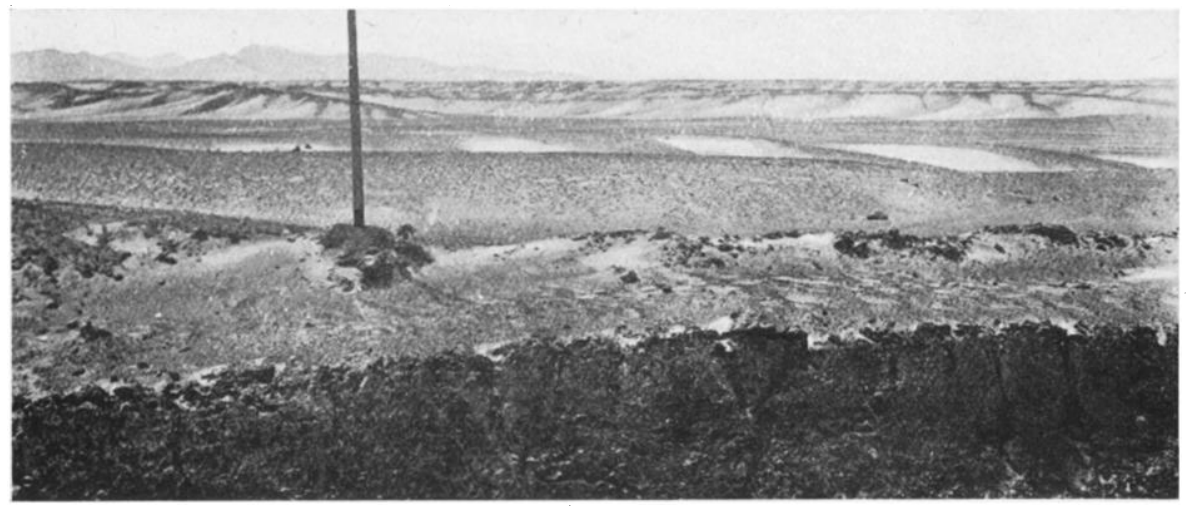

CONGLOMERATE BED OF PAMPA DEL SACRAMENTO, AND MODE IN WHICH THE SANDHILLS ARE DERIVED FROM IT

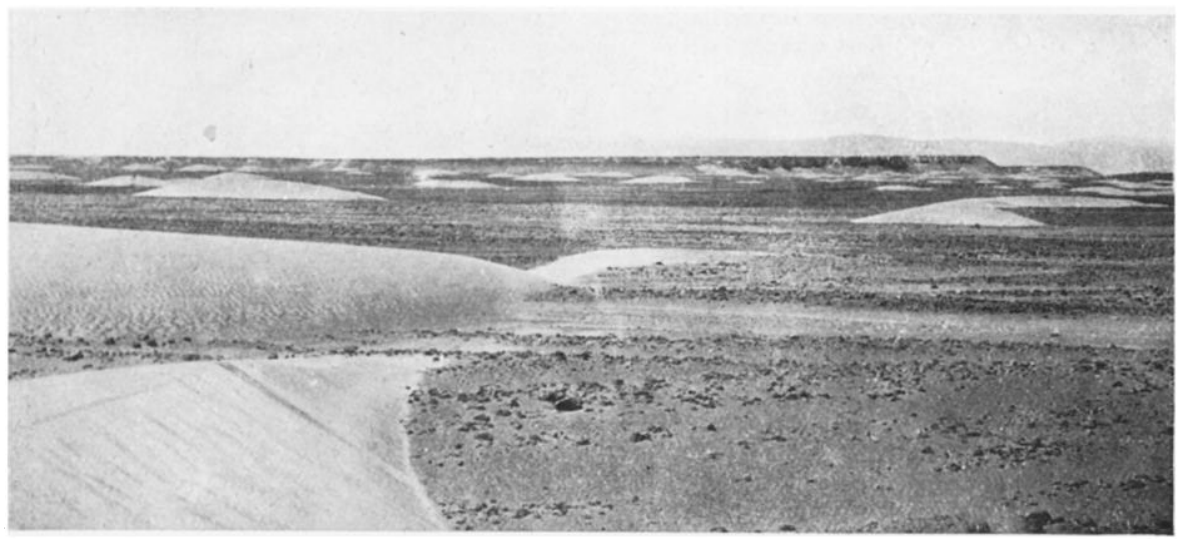

ARRANGEMENT OF DUNES: PLATEAU OF CONGLOMERATE FROM WHICH THEY ARE DERIVED, AND PEBBLE-STREAM SURFACE OF PAMPA

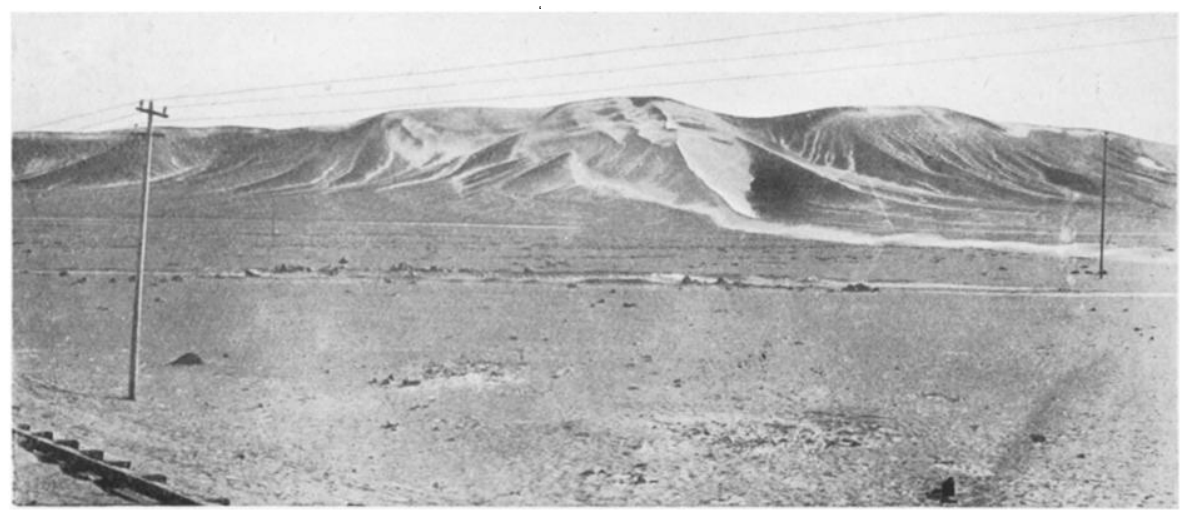

SAND-DUNES CROSSING THE RIDGES ON PAMPA DEL SACRAMENTO 


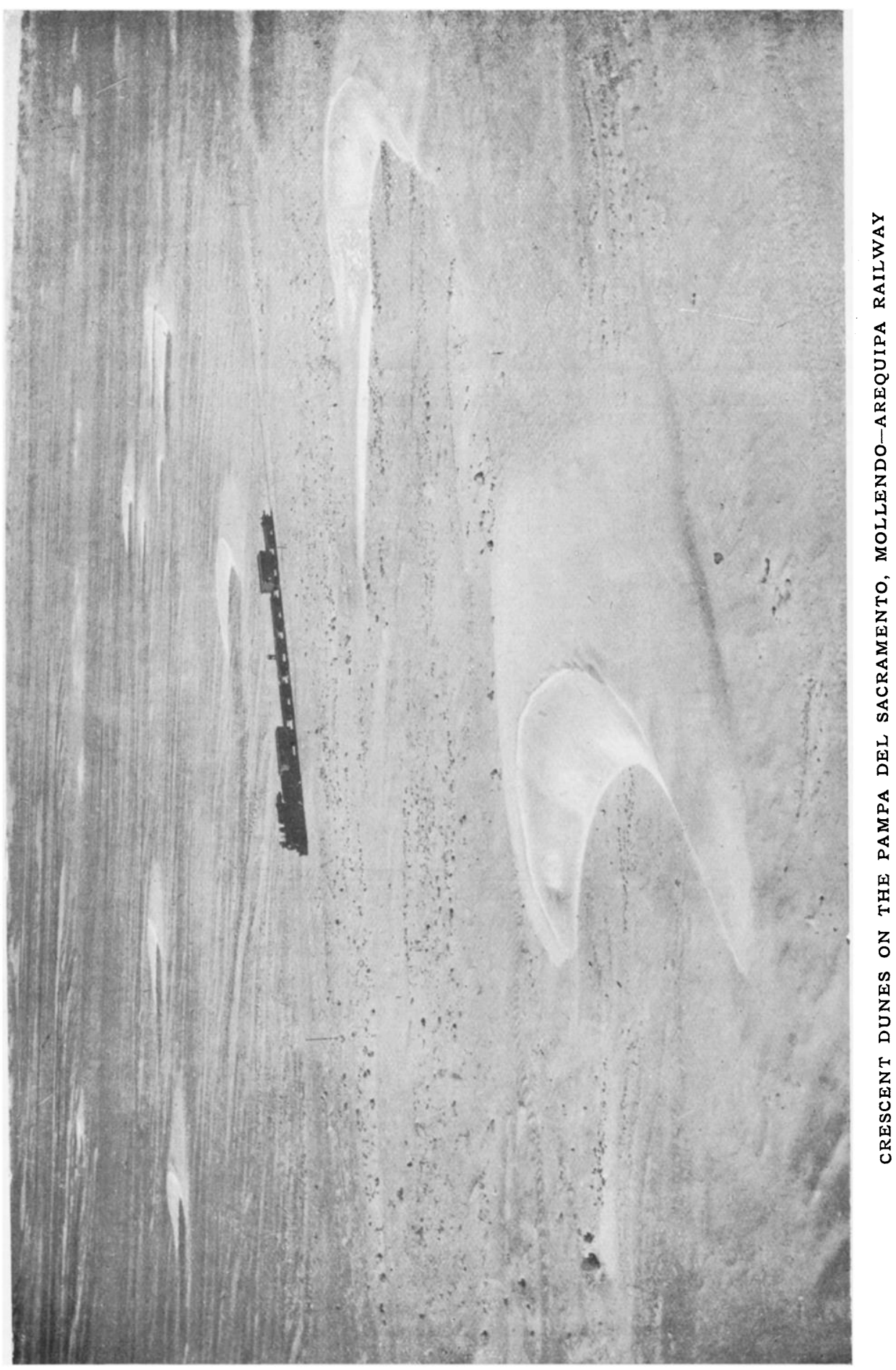

This content downloaded from 128.255.6.125 on Tue, 31 May 2016 08:11:55 UTC All use subject to http://about.jstor.org/terms 
The march of the dunes is assisted by the sand ripples, whose more exposed surfaces are blown onward by the wind. The sand climbs the steep back of the dune more slowly than the low salient wings-hence the half-moon shape. Small particles travel at relatively high speed near ground-level as far as the projecting points, or horns, but as soon as they reach them they are in the lee of the wind and their further progress is checked until the mass of the dune catches up. Thus the distance the sand travels along the points is dependent on the maximum height of the back of the dune, and this in turn depends on the force of wind. The stronger the wind the higher it will force up the sand particles in a direct right angle to the axis of the dune, i.e. to a line drawn between the horns. The shape of any given dune is therefore the result of a perfectly graduated balance between the wind-force and the floor-level. The railway track in crossing the desert shows an average rise of slightly over $\mathrm{I}$ in Ioo, so that although their shape is governed by surface variations the dunes are on the whole marching uphill.

Owing to my short stay in the Pampa I was not able to check the dunes' rate of march by personal observation, but I was informed by plate-layers and other railway-men whose duties necessitate watching them, that the rate is about roo yards per annum. The high hills flanking the desert near Arequipa are too steep to allow the dunes to proceed further. They therefore pile up in a sort of sandy cemetery at the eastern edge of the Pampa. Before they reach the end, however, and as the hills deflect the air in different directions, dunes occasionally advance over or threaten the railway line. The method of avoiding the threatened obstruction is simple but efficient. A couple of men go out with long-handled spades and a wheelbarrow and collect loose pebbles and grit from the surface of the Pampa. This they proceed to scatter in a thin layer over the back of the unfortunate dune. The pebbles arrest the action of the ripples and so interfere with the even circulation of the sand particles, which is apparently as essential to the progress of the dune as the circulation of blood to a human being. Very shortly the dune assumes a lopsided shape, sagging where the débris has been cast upon it and offering, instead of a well-rounded back, a breach to the action of the wind. The process of disintegration is fairly rapid, and at the end nothing is left on the Pampa except the original wheelbarrow loads of grit and pebbles which sufficed to exorcise the monster.

The dunes advance over pebbles and stones without disturbing their position. I noticed immediately behind several large dunes scattered stones (which may also be noted in the photographs) that obviously had not shifted from their bed, just as pebbles may lie secure on the seashore in the swell of the breakers. Generally speaking, the smoother the surface of the Pampa and the higher the wind, the larger and more perfect becomes the dune.

The Pampa del Sacramento is a true desert without a vestige of 
vegetation, even immediately after cloud-bursts, the wind-blown sand being apparently fatal to nascent growth. Outside the influence of the desert wind the soil, as in the case of Egypt, is extremely fertile under irrigation. But on the desert surface of the Pampa there are not even insects. The sand preserves its contents well. A quantity of flint-locks, dating from early Spanish times, were found; also the body of a mummified woman, who probably died during the construction of the railway forty years ago. The Vitor stream which crosses the Pampa on the northern fringe of the sand-dunes formed a recognized route in the journey from the coast to Lake Titicaca even in the time of the early Spanish occupation. Both for those early travellers and for the railway the beacon that points the way across the dreaded desert remains the same-the twin snow-clad summits of Misti and Horcones, the irrigation from which makes of Arequipa a green oasis in this sterile wilderness of hills.

\section{NOTES ON THE KIRIN PROVINCE, MANCHURIA}

$\mathrm{M}^{\mathrm{R}}$

R. K. H. von Lindholm, the Commissioner of Chinese Customs at Hunchun in South-east Manchuria, has sent the Society some notes on the country around his post, to supplement a report of his which was published in the last series of Decennial Reports of the Chinese Maritime Customs (I902-I9II). This region came into prominence a few years ago because of a dispute with Japan, in which a claim was made that it properly came within Japanese jurisdiction as a part of Korea.

Hunchun was "opened" to trade by the Manchurian Convention which was concluded between China and Japan in 1905. It lies on an affluent of the Tumen ro miles from the Korean boundary and 15 miles from the Russian. It is comparatively modern and dates from I 7 I4, when K'ang-hsi established a small military post there dependent on Nuiguta. But the country around is said to have a history dating back to the Sung dynasty ( $\mathrm{r}$ th century) when it was known as Hai-lan-lu, a name which was changed to Hai-lan-fu under the Mongol Yüans (I $3^{\text {th }}$ and I $4^{\text {th }}$ centuries), and to Chien-chou-wei during the Ming Dynasty ( 14 th to I 7 th centuries). At the time of the Manchu conquest of China these parts were inhabited by Manchus (Nüchên), who had absorbed Yüpitatse ("Fishskin Tartars") as well as remnants of earlier Korean colonies. The campaigns of the Manchus are said to have drained the population to the point of extinction, and when Europeans first made practical acquaintance with the region in

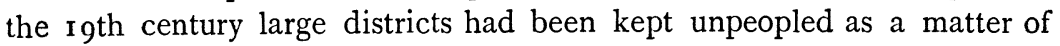
policy by the Manchu emperors. The Koreans were told that their frontier was the 'Tumen, and for centuries they had been forbidden to cross it under the severest penalties. About forty or fifty years ago the prohibition was relaxed to the extent that Chinese colonists from Shantung and Chihli were encouraged to settle all along the Korean borderlands, and the 